\title{
Specificities of the estimation of efficiency of investment and construction projects at various stages of their life cycle
}

\author{
Aleksandr Bobkov ${ }^{*}, 1$, Boris Orlov ${ }^{1}$, Nadezhda Belozerova ${ }^{2}$, Ivan Provotorov $^{3}$ and Irina \\ Kozlova $^{4}$ \\ ${ }^{1}$ Moscow state University of technology and management. K.G. Razumovsky, Zemlyanoy Val street, \\ 73, Moscow, 109004, Russia \\ ${ }^{2}$ Saint-Petersburg State Economic University, Sadovaya st. 21, St. Petersburg, 191023, Russia \\ ${ }^{3}$ Voronezh State Technical University, Moscow Avenue, 14, 394026, Voronezh, Russia \\ ${ }^{4}$ Moscow State University of Civil Engineering, 129337, Yaroslavskoye shosse, 26, Moscow, Russia
}

\begin{abstract}
The paper addresses the issues related to the specificities of the estimation of efficiency of investment and construction projects (further ICP) at various stages of their life cycle. The structure of the ICP was analyzed; the necessity of detailed decomposition of the life cycle in order to improve the efficiency of block-process management was justified. The sequence of key organizational events in the implementation of the ICP is presented. The comparative analysis of methods for determining the discount rate was carried out. The methodology of the integrated approach to the organization of analysis of investment and construction projects is offered, which is characterized by close connection with the concept of the investment project's life cycle. It promotes fuller compliance with the goals and objectives of investment and construction entities at all stages of investment, management and financial decision-making.
\end{abstract}

\section{Introduction}

The estimation of efficiency of investment projects in terms of economic feasibility and social significance is crucial in the selection of the best projects. Qualitatively conducted investment analysis allows making the optimal decisions in conditions of multi-variant use of limited resources for obtaining the best financial results. Therefore, it is very important to estimate the project in the course of pre-design studies, on which its viability and investment attractiveness will depend.

The estimation of ICP efficiency are based on the following basic principles applicable to all types of projects independently from their technical, technological, financial, industrial or regional characteristics $[1,2]$.

- consideration of the project throughout its life cycle;

- modeling of cash flows for the accounting period;

- principle of positivity and maximum effect;

\footnotetext{
*Corresponding author: doctorbobkov@mail.ru
} 
- accounting of the time factor;

- accounting only the future costs and income;

- accounting of all the most significant consequences of the project;

- accounting of the different project participants that expressed in individual values of the discount rate;

- multi-stage estimation;

- accounting of the influence of working capital requirements on project efficiency;

- influence of uncertainties and risks.

\section{Materials and methods}

The general scheme for estimating the efficiency of the project is conducted in three stages (Fig. 1):

1. The initial step is an expert estimation of the social significance of the project. Largescale, national economic and global projects are considered to be socially significant.

2. At the second stage the project's efficiency indicators are calculated in general. Only the commercial efficiency is estimated for the local projects. If this efficiency is acceptable, it is recommended to go directly to the next stage of the estimation. The social and economic efficiency is primarily estimated for socially significant projects.

3. The third stage of the estimation is conducted after the development of the financing scheme. At this stage the membership is specified and financial feasibility and efficiency of participation of each participant in the project are determined $[3,4]$.

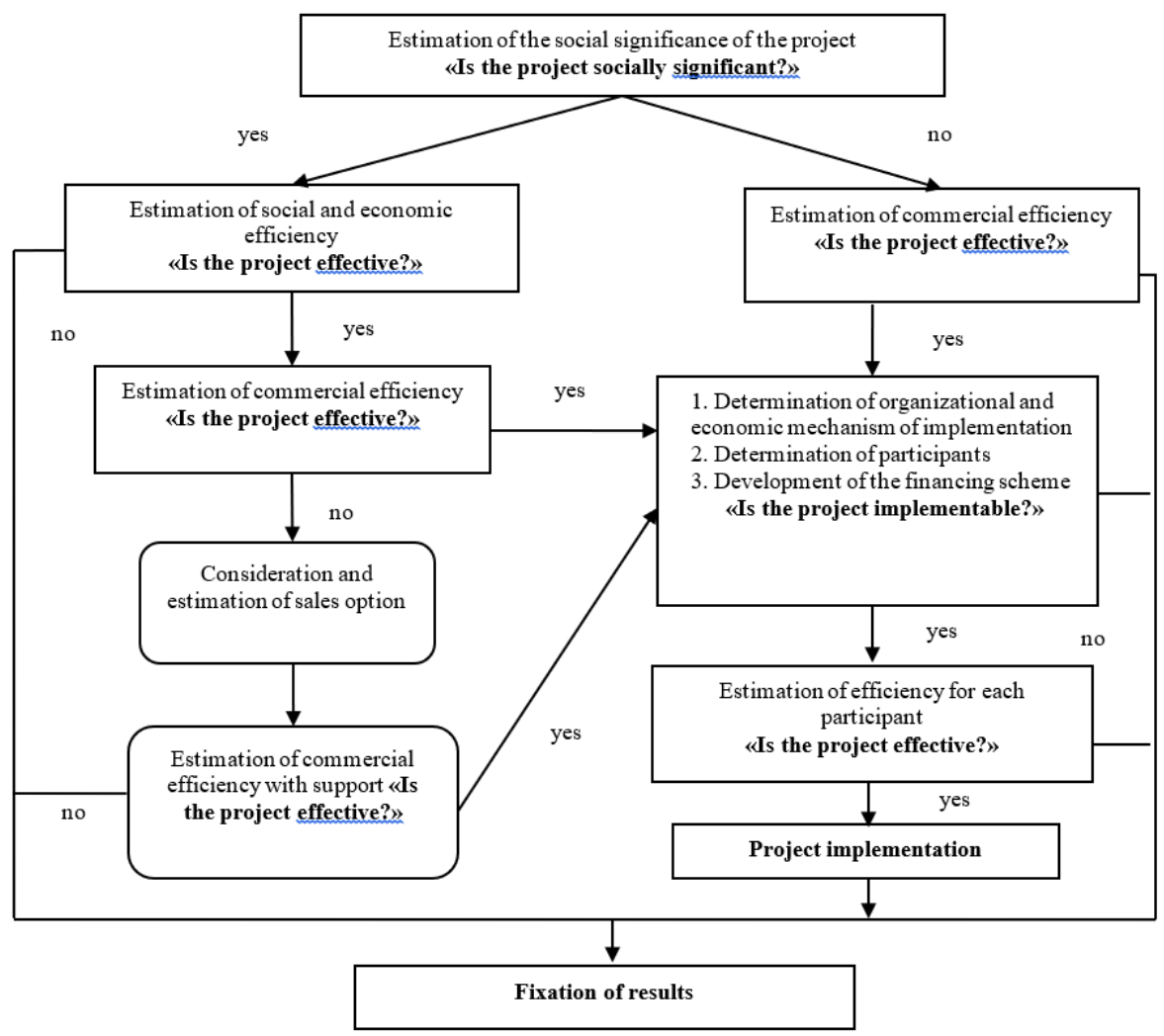

Fig. 1. Scheme for estimating the efficiency of the investment and construction project. 
Estimation of ICP efficiency can and should be done more than once at the initial stage of pre-design studies. Taking into account that the data on the project are subject to review at each stage, the number of conducted efficiency estimation is unlimited and is determined by the needs and requirements of the investor. In conditions of obtaining additional information and clarifying the initial data on the project at each stage of its life cycle, it was suggested to use a different efficiency estimation structure based on the use of appropriate methods of estimation (Fig. 2). Estimation of ICP at different stages of its life cycle is necessary for the possibility of performance management. It should be noted that the originally formulated objectives should not be considered as something constant. The objectives can change during the implementation of the project. Terms, construction technology and cost can also be adjusted. Such changes occur during project management and are aimed at achieving the "project success" [5,6].

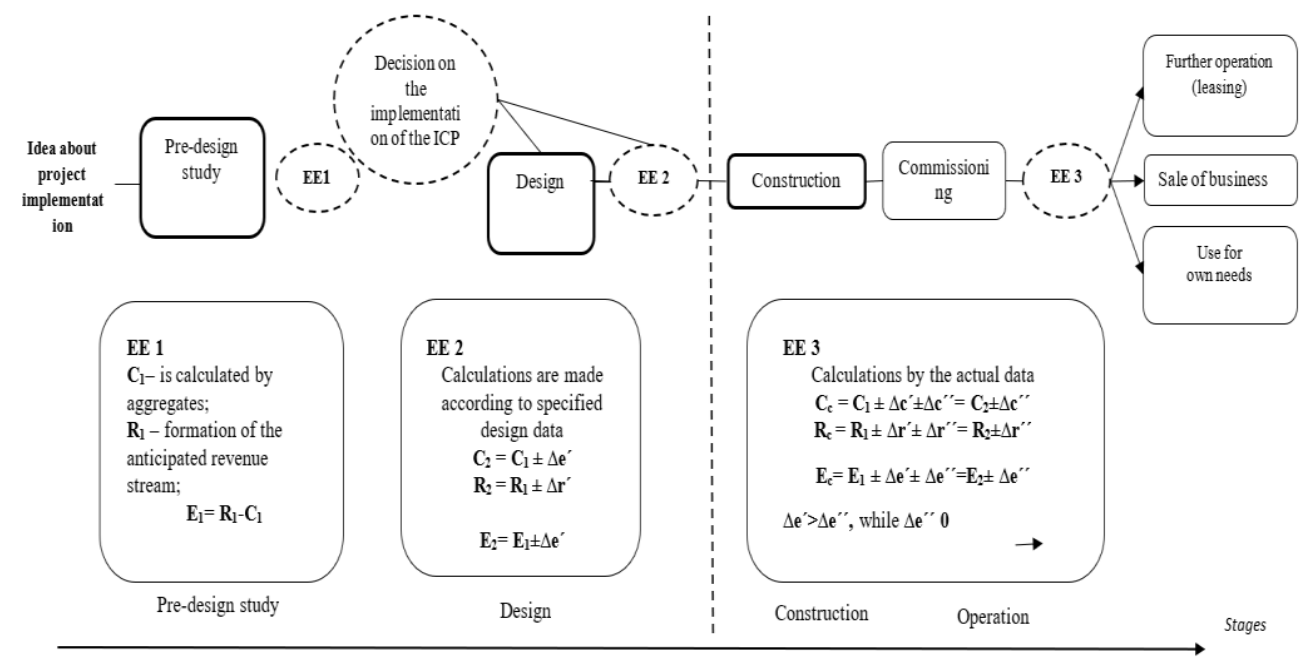

Fig. 2. Estimation of ICP efficiency in process of clarification of initial data, where EE - estimation of efficiency, $\mathrm{C}$ - cost of construction and installation works, expenses, $\mathrm{R}$ - revenue, selling price, $\mathrm{E}$ - efficiency, $\Delta \mathrm{c}$ - delta of cost (expenses), $\Delta \mathrm{r}$ - delta of revenue, $\Delta \mathrm{e}$ - delta of efficiency.

Estimation of ICP efficiency is an important criterion in an investment decision-making. Based on the results of estimation, the investor chooses the best investment option in terms of tradability, payback and profitability. It is necessary to consider the initial data of the analyzed project to perform calculations of indicators that characterize the efficiency. Each ICP has the time frame, in other words, the accounting period during which outflows and inflows of cash occur. In this regard, determination of the discount rate is one of the most difficult tasks in estimation of ICP efficiency [7,8].

\section{Results}

The results of ICP efficiency indicators, and therefore the estimation of efficiency, significantly depend on the established discount rate. This leads to the necessity of a reasoned justification of the method used to determine the discount rate and the values of the used parameters, as well as making alternative calculations for all project participants with the possible application of a variable discount rate for different steps of calculation. Today, there are many methods for determination of the discount rate [9]. The advantages and disadvantages of each are listed in Table 1.

Table 1. Methods for determination of the discount rate, their advantages and disadvantages. 


\begin{tabular}{|c|c|c|c|}
\hline $\begin{array}{l}\text { Name of the } \\
\text { method }\end{array}$ & $\begin{array}{l}\text { Description of the } \\
\text { method }\end{array}$ & Advantages & Disadvantages \\
\hline $\begin{array}{l}\text { Cost of equity } \\
\text { (CAMP ( } \\
\text { (Capital Asset } \\
\text { Pricing } \\
\text { Model)) }\end{array}$ & $\begin{array}{l}\text { Estimates the cost of } \\
\text { equity of the company }\end{array}$ & $\begin{array}{l}\text { Is the most } \\
\text { reasonable method } \\
\text { with the necessary } \\
\text { amount of data }\end{array}$ & $\begin{array}{l}\text { 1. Instability of the stock } \\
\text { market; } \\
\text { 2. Impossibility of application } \\
\text { in the absence of information } \\
\text { on stock quotes of the } \\
\text { estimated company }\end{array}$ \\
\hline $\begin{array}{l}\text { Weighted } \\
\text { average cost } \\
\text { of capital } \\
\text { (WACC) }\end{array}$ & $\begin{array}{l}\text { Estimates the cost of } \\
\text { equity and debt } \\
\text { attracting for financing }\end{array}$ & $\begin{array}{l}\text { The most objective } \\
\text { and frequently used } \\
\text { method }\end{array}$ & $\begin{array}{l}\text { 1. Is the aggregated method of } \\
\text { calculation; } \\
\text { 2. Averages the risks }\end{array}$ \\
\hline $\begin{array}{l}\text { Cumulative } \\
\text { structure }\end{array}$ & $\begin{array}{l}\text { Addition of a risk-free } \\
\text { rate of return and } \\
\text { various risk factors }\end{array}$ & $\begin{array}{l}\text { 1. Simplicity and } \\
\text { easiness of } \\
\text { application; } \\
2 \text {. The ability to } \\
\text { estimate the risks } \\
\text { associated with the } \\
\text { implementation of } \\
\text { the project }\end{array}$ & $\begin{array}{l}\text { 1. The method is based on the } \\
\text { additivity of risk factors, } \\
\text { which leads to the } \\
\text { consideration of one factor } \\
\text { several times; } \\
\text { 2. Expert or individual } \\
\text { estimation of risk factors, the } \\
\text { results of which cannot be } \\
\text { scientifically based }\end{array}$ \\
\hline $\begin{array}{l}\text { Expert } \\
\text { estimation }\end{array}$ & $\begin{array}{l}\text { Expert acceptance of } \\
\text { discount rates for } \\
\text { various groups of } \\
\text { analog projects }\end{array}$ & Easy to use & $\begin{array}{l}\text { 1. Subjective opinion; } \\
\text { 2. There is no serious } \\
\text { justification for the established } \\
\text { normative values }\end{array}$ \\
\hline $\begin{array}{l}\text { Individual } \\
\text { alternatives }\end{array}$ & $\begin{array}{l}\text { Accepting of the } \\
\text { discount rate at one } \\
\text { level for all project } \\
\text { groups }\end{array}$ & Easy to use & $\begin{array}{l}\text { The method does not take into } \\
\text { account the level of project } \\
\text { risk, industry affiliation, } \\
\text { economic situation in the } \\
\text { country }\end{array}$ \\
\hline
\end{tabular}

\section{Discussion}

Any ICP should ensure the recovery of the invested funds through the sales revenue, ensure profitability and return on investment. It is necessary to estimate the efficiency of a knowingly loss-making ICP at the stage of pre-design studies in order to avoid making irrational decisions on its implementation $[10,11]$.

Taking into account that the project data are subject to review at each stage, the number of estimations of efficiency is not limited and is determined taking into account the necessities and requirements of the investor. This estimation is necessary for the ability to manage the project and its efficiency.

\section{Conclusion}

The long life cycle of the project, the increase in the estimated cost in the construction process, the lack of adequate sources of financing, underestimation of industry specifies all of this negatively affects the design and construction works. One of the most important and complex tasks that needs to be addressed during the justification and estimation of investment projects is the task of determination of the discount rate. The correct choice of the discount rate significantly affects the accuracy of the economic efficiency indicators of the estimated investment project. This is due to the high sensitivity of the result of calculations from the value of the discount rate. This leads to the necessity of a reasoned 
justification of the method used to determine the discount rate and the values of the used parameters, as well as making alternative calculations for all project participants with the possible application of a variable discount rate for different steps of calculation.

\section{References}

1. J. Panibratov, World Applied Sciences Journal 23, 144-148 (2013)

2. N. Safronova, E. Nezhnikova, A. Kolhidov, MATEC Web of Conferences, doi: 10.1051/matecconf/201710608024

3. V. Kankhva, MATEC Web of Conferences 106, 08027 (2017) doi: 10.1051/matecconf/201710608027

4. V. Kankhva, E3S Web of Conferences, 33 (2018) doi: 10.1051/e3sconf/20183301036

5. E. Nezhnikova, O. Papelniuk, A. Gorokhova, International Journal of Energy Economics and Policy 8(1), 203-211 (2018)

6. I. Ptuhina, T. Spiridonova, T. Musorina, S. Kanyukova, A. Rezvaia, MATEC Web of Conferences 53, 01049 (2016)

7. D.N. Silka, MATEC Web of Conferences, 07012 (2016)

8. R.S. Golov, V.V. Shilov, S.A. Silantiev, ASEE International Forum, 20766 (2017)

9. A.K. Orlov, I.Y. Chubarkina, MATEC Web of Conferences 106, 08015 (2017)

10. O. Kalinina, O. Valebnikova, Advances in Intelligent Systems and Computing 692, 1315-1322 (2018) doi: 10.1007/978-3-319-70987-1_139

11. S.S. Uvarova, I.G. Lukmanova, Izvestiya Vysshikh Uchebnykh Zavedenii 3, 369 (2017) 